\title{
A RÖVID TÁVÚ EMLÉKEZET ÉS A MUNKAMEMÓRIA ONLINE MÉRÉSE: CORSI, SZÁMTERJEDELEM ÉS N-VISSZA*
}

\author{
KOVÁCS KRISTÓF ${ }^{1}$ - FARAGÓ BOGLÁRKA ${ }^{1}$ - KÖVI ZSUZSANNA² - \\ RÓZSA SÁNDOR ${ }^{3}$ - DÁVID MÁRIA ${ }^{1}$ \\ ${ }^{1}$ Eszterházy Károly Főiskola, Eger; ${ }^{2}$ Károli Gáspár Református Egyetem; \\ ${ }^{3}$ Washington University, St. Louis, Egyesült Államok \\ e-mail: kristof340@gmail.com; faragobogi89@gmail.com
}

Beérkezett: 2015. október 15. - Elfogadva: 2015. november 20.

\begin{abstract}
A rövid távú emlékezet és a munkamemória mérésére számos különböző eszközt dolgoztak ki, a számterjedelemtöl a komplex terjedelmen át az $N$-vissza feladatig. Jelen cikk áttekinti az emlékezeti terjedelem mérésének elméleti és módszertani kérdéseit, kitérve a munkamemória-kapacitás területáltalános jellegére, fluid intelligenciával és iskolai teljesítménnyel való kapcsolatára, valamint az életkori különbségekre is. Bemutatásra kerül öt, az emlékezeti terjedelem laboratóriumi vagy online környezetben való mérésére alkalmas feladat magyar változata: a Corsi- és a számterjedelmi feladat oda és visszafelé mért változatai, valamint az $N$-vissza feladat. A feladatok magyar változatát nagyjából 1000 fös, három életkori csoportot (10, 14 és 18 évesek) tartalmazó mintán vettük fel. Az emlékezeti feladatok életkori változásain és egymással való kapcsolatán kívül bemutatjuk a fontosabb percentilis értékeket tartalmazó normatáblázatokat is.
\end{abstract}

Kulcsszavak: rövid távú emlékezet, munkamemória, emlékezeti terjedelem, fluid intelligencia, online mérés

\footnotetext{
* Köszönetnyilvánítás: a szerzők hálásak Dorner Lászlónak, Fürné Mosoni Anitának, Marton Klárának és az Eszterházy Károly Főiskola Pszichológia Tanszék munkatársainak a feladatok elkészítésében és felvételében nyújtott segítségükért.
}

A közlemény a Társadalmi Megújulás Operatív Program Digitális átállás az oktatásban címet viselő, 4.2.2.D-15/1/KONV-2015-0027 azonosítószámú projekt keretében készült. A projekt az Európai Unió támogatásával és az Európai Szociális Alap társfinanszírozásával valósult meg. 


\section{A MUNKAMEMÓRIA FOGALMA}

A munkamemória elmélete Alan Baddeley és Graham Hitch nevéhez köthető (Baddeley és Hitch, 1974), és az Atkinson- és Schiffrin-féle klasszikus rövid távú emlékezeti modell (Atkinson és Shiffrin, 1968) kritikájából nőtt ki. Atkinson és Schiffrin szerint a környezetből érkező információk első állomása a szenzoros emlékezet (amely inkább a perceptuális rendszer része), majd onnan kerülnek a limitált kapacitású rövid távú tárba, ahonnan a hosszú távú emlékezetbe kerülhetnek. Atkinson és Schiffrin modelljével kapcsolatban azonban felmerültek problémák. A modell szerint a rövid távú emlékezet nélkülözhetetlen egyebek között a hosszú távú tanuláshoz. Ugyanakkor megfigyelték, hogy azok a betegek, akiknek a rövid távú emlékezeti rendszerük sérült, az esetek túlnyomó részében jól működő hoszszú távú emlékezettel rendelkeztek.

Baddeley és Hitch a rövid távú emlékezet helyett bevezette a három komponensű munkamemória modellt: e szerint a munkamemóriának van egy tárolási és feldolgozási képességet limitáló kontrollrendszere, a központi végrehajtó, valamint két passzív tár, egy nyelvi (fonológiai hurok) és egy téri (téri-vizuális vázlattömb). Azon betegeknél, akiknél a csökkent rövid távú emlékezeti kapacitás ellenére nem romlott a hosszú távú tanulási képesség, valószínűleg a munkamemóriának csak a fonémikus ismétlési összetevője sérült, míg a központi végrehajtó komponens érintetlen maradt (Baddeley és Hitch, 1974). A modell szerint a munkamemória központi végrehajtó eleme felelős a figyelmi kontrollért, a fonológiai hurok feladata a beszédalapú információ fenntartása, beleértve a számokat is a számterjedelem-tesztben, míg a téri vizuális vázlattömb végzi a téri-vizuális képek fenntartását és manipulációját (Baddeley, 1992; Anderson, Baddeley és Eysenck, 2010).

Ericsson és Kintsch (1995) egy másik fogalmi keretben használják a munkamemória fogalmát. Számukra ez lényegében a hosszú távú emlékezeti tár aktivált részeit jelenti. A Baddeley- és Hitch-féle modell legismertebb alternatívája azonban a Nelson Cowan nevéhez füződő „beágyazott folyamat modell” (embedded process model; Cowan, 1999), amely szerint három, egymásba ágyazott emlékezeti rendszer felelős az információ rövid távú tárolásáért és kognitív tevékenységekben való használatáért. Az első, legtágabb szint a hosszú távú memória, amelynek éppen aktivált része jelenti a második szintet, mely az elvégzendő feladat szempontjából releváns információt hozzáférhetően tartja. A harmadik, legszúkebb folyamat pedig a figyelmi fókusz: az aktivált információnak az a szelete, amelyre éppen tudatosan odafigyelünk. A figyelmi fókusz igen limitált kapacitású: nagyjából négy elemhez vagy információhalmazhoz való hozzáférést biztosít (Cowan, 2001).

Klaus Oberauer és munkatársai „hármas beágyazott folyamat modellje” (threeembedded-component model, Oberauer és Hein, 2012) lényegében kiegészítése Cowan modelljének. A modell szintén három komponenst feltételez: az egyik a hosszú távú emlékezet aktivált része, amely az elvégzendő feladat szempontjából releváns információt hozzáférhetően tartja, a második a direkt hozzáférés területe (ez Cowan figyelmi fókuszának felel meg), végül a harmadik komponens a szukk figyelem fókusza, amely Cowan felfogásával szemben csupán egyetlen elemet helyez a középpontba. Ez utóbbi két összetevő együttesét nevezi Oberauer szélesebb 
fókusznak. A szélesebb figyelem fókuszában lévő itemek számának növekedése lelassítja a hozzáférést, mert ezek interferálhatnak egymással. Ugyanakkor a modell szerint az információ aktívan fenntartható a széles figyelmen kívül a hosszú távú emlékezetben is.

A Baddeley- és a Cowan-féle munkamemória-felfogás egyik legfőbb különbsége, hogy míg az előbbi szerint a passzív területspecifikus tárak határozzák meg egymástól függetlenül - a téri és nyelvi kapacitást, addig az utóbbi a figyelem fókuszának általános limitáló hatását hangsúlyozza. Ugyanakkor a két felfogás számos hasonlóságot is mutat. Egyrészt mindkettő megkülönbözteti a passzív tárolást az aktív feldolgozástól. Másrészt a Cowan-modell második szintje, az éppen aktivált információ sok szempontból hasonlít a Baddeley-modell passzív tároló rendszerére, hiszen egyik sem igényel aktív figyelmet. Végül a központi végrehajtó és a figyelmi fókuszért felelős folyamat fogalmilag sok szempontból hasonló. További jelentős modellek is ennek a rendszernek a központi szerepére mutatnak rá, így például Engle és Conway (Conway, Macnamara, Getz és Engel de Abreu, 2011; Engle és Kane, 2004) a „végrehajtó figyelem” központi szerepét hangsúlyozzák, amely meghatározza a munkamemória kapacitását, és amely mindkét modell figyelmi komponensével mutat hasonlóságokat.

Összességében a munkamemória különféle modelljeiben közös, hogy a rövid távú emlékezeti modellel szemben egyrészt a modalitásspecifikus reprezentációk meglétét hangsúlyozzák, másrészt az információ rövid távú tárolásáért és előhívásáért felelős kognitív mechanizmusokat egy aktív rendszerként képzelik el, amely fontos kognitív tevékenységekben vesz részt a problémamegoldástól a szövegértésig, nem pedig egy passzív tárhelyként, amelyen az információ „áthalad” a szenzoros emlékezettől a hosszú távú memória felé.

\section{A MUNKAMEMÓRIA MÉRÉSE}

A munkamemória kapacitásának mérése a konstruktum aktív rendszerként való felfogását operacionalizálja, az azonnali memória rendszer funkcionális fontosságát hangsúlyozva. Vagyis olyan feladatokból indul ki, amelyekhez limitált mennyiségű információ rövid ideig való tárolására van szükség párhuzamosan zajló mentális aktivitás közben.

Számos, az olvasási és hallási terjedelemhez hasonló feladat született az elmúlt évtizedekben. Ezeket átfogóan komplex terjedelmi feladatnak nevezik, szembeállítva az egyszerủ terjedelmi feladatokkal, mint például az egyszerű szó- vagy számterjedelem. A komplex terjedelmi feladatok fogalmilag azért alkalmasak a munkamemória mérésére, mert egyszerre igénylik a munkamemória tárolási és feldolgozási funkcióját azáltal, hogy a feladat szempontjából releváns információt kell fejben tartani kognitív feladatok végrehajtása közben. Emellett, mivel a mondatokat rövid ideig prezentálták (csak annyi időre, míg a személy el tudja olvasni őket), ez megakadályozta a megjegyzendő szavak ismételgetését, a munkamemória kapacitását pedig az az információmennyiség tükrözi, amelyet a személyek aktívan fenn tudnak tartani ismételgetés nélkül. 
Az első ilyen jellegű feladatok a számolási terjedelem (Case, Kurland és Goldberg, 1982) és az olvasási terjedelem (Daneman és Carpenter, 1980). A számolási terjedelem feladatban különböző alakzatokkal teli képernyők jelennek meg egymás után. Az egyes képernyőkön hangosan meg kell számolni az alakzatokat, majd megjegyezni a végeredményt, és az utolsó képernyő után meg kell ismételni az alakzatok számának összegeit a képernyők megjelenésének sorrendjében. Az olvasási terjedelem feladatban pedig mondatokat kell olvasni (az eredeti változatban hangosan, az újabb, számítógépes változatokban el kell dönteni, hogy a mondatok értelmesek-e), közben megjegyezni a mondatok utolsó szavát, majd az utolsó mondatot követően felidézni a szavakat az eredeti sorrendben.

A komplex terjedelmi feladatok a munkamemória-kapacitás valid és reliábilis mérőeszközei (Conway és mtsai, 2005). Számos komplex terjedelmi feladatból készült automatizált, számítógépes változat is. Az automatikus komplex terjedelmi feladatok gyors adminisztrációt tesznek lehetővé, automatikus pontozásúak, a próbák és a listahosszúságok random kombinációját generálják, olyan felidézendő elemeket tartalmaznak, melyek a feldolgozási feladattól elkülönülnek, és minden próba végén visszajelzést adnak a feldolgozás és tárolás pontosságáról.

A munkamemória mérésére azonban a komplex terjedelem mérésén kívül több más feladatot is kidolgoztak. Bizonyos módszertani módosítások bevezetésével (például rendkívül gyors bemutatás) az egyszerű terjedelmi feladatok is mérhetik a munkamemóriát, pontosabban közvetlenül a figyelmi terjedelmet.

A figyelmi terjedelmet mérik egyes vizuális összehasonlítást igénylő feladatok is. Az egyikben például a vizsgálati személyek először egy négyzetrácsos hálóban látnak négy különböző alakzatot, melyek közül kettő kör, kettő háromszög, mindegyik más-más színben. Ezt követően újra megjelenik a háló, de csak egyetlen elemet tartalmaz, amelyről a személynek meg kell állapítania, hogy az eredeti elrendezésben melyik elemmel volt azonos alakzatú és színű, és meg kell jelölnie a hálóban azt a helyet, ahol a próbaalakzattal megegyező eredeti elem az első bemutatás során szerepelt (Cowan, Saults és Clark, 2015).

Alkalmasak a munkamemória mérésére az úgynevezett koordinációs és transzformációs próbák is, melyek során a prezentált információt manipulálni vagy transzformálni kell a helyes válasz elérése érdekében. Ilyen például a „betű-szám szekvencia" feladat (Gold, Carpenter, Randolph, Goldberg és Weinberger, 1997), amelyben a személy betúk és számok kevert sorozatát kapja, majd azokat a bemutatás után sorba (a számokat növekvő, a betűket ábécésorrendbe) rendezve kell visszamondania. De ide tartoznak a visszafelé mért terjedelmi tesztek is, amelyekben az elemeket fordított sorrendben kell előhívni, mint ahogy prezentálták őket. A jelen cikk szempontjából különösen fontos, hogy a fordított számterjedelemfeladat is sok szempontból közelebb áll a munkamemóriához, mint az egyszerü terjedelemhez, hiszen egy időben szükséges tárolni és manipulálni az információt a feladat megoldása közben. Továbbá a kognitív képességtesztekkel való korrelációs mintázatokat tekintve is jobban hasonlít a visszafelé számterjedelem a betűszám szekvenciára, mint az egyszerű számterjedelmi feladatra (Kovacs és mtsai, kézirat). 
Végül az utolsó csoportot alkotják az N-vissza feladatok, ahol ingerek sorozatában kell meghatározni, hogy az aktuális inger megegyezik-e az N-nel (eggyel, kettővel, hárommal stb.) előbb látott ingerrel. Az N-vissza feladat helyes megoldásához arra van szükség, hogy folyamatosan frissítsük a munkamemória tartalmát, vagyis ne csak megjegyezzünk ingereket, hanem folyamatosan töröljük az N-nél korábbi ingereket. Az N-vissza feladatok részletes bemutatását lásd a feladatok leírását tartalmazó részben.

Magyarországon Németh Dezső és munkatársai (Németh, Racsmány, Kónya és Pléh (2001) foglalták össze az emlékezeti terjedelem mérésére használható feladatokat, a hallási mondatterjedelem teszt, egy komplex terjedelmi feladat magyar adaptációját pedig Janacsek Karolina és munkatársai (Janacsek, Tánczos, Mészáros és Németh, 2009) készítették el. A teszt alkalmas a munkamemória életkori változásának feltérképezésére, hiszen még olvasni nem tudó gyerekek esetében is alkalmazható, és az olvasás egyéni különbségeit is kiküszöböli. A feladat során a vizsgálatvezető felolvas egy mondatot, melyről a vizsgálati személy eldönti, hogy igaz vagy hamis, majd a cél a mondatok utolsó szavainak elhangzási sorrendben való visszamondása. A mondatok száma egyre nő mindaddig, míg a helyes sorrendben vissza tudja mondani őket a személy. A feladat lényegében azonos az olvasási terjedelem számítógépes változatával, azzal a különbséggel, hogy itt a személy nem maga olvassa a mondatokat, hanem felolvassák neki.

\section{A MUNKAMEMÓRIA TERÜLETÁLTALÁNOSSÁGA, FLUID INTELLIGENCIÁVAL ÉS ISKOLAI TELJESÍTMÉNNYEL VALÓ KAPCSOLATA}

Daneman és Carpenter (1980) az olvasási terjedelem feladat bevezetésével együtt megmutatták, hogy annak eredménye meglepően magasan korrelál különféle verbális teszteredményekkel, elsősorban a szövegértéssel. Ezt ők azzal magyarázták, hogy a jobban olvasóknak több kognitív erőforrásuk marad a feladat emlékezeti komponensére, vagyis lényegében a jobb olvasás okozza a magasabb olvasási terjedelmet.

Turner és Engle (1989) ugyanakkor vitatták ezt a magyarázatot, és a munkamemória-kapacitás területáltalánosságára igyekeztek rámutatni. Szerintük a jobban olvasók nagyobb munkamemória-kapacitással bírnak a kevésbé jól olvasóknál akkor is, ha a munkamemória-kapacitást nem az olvasási terjedelem feladattal mérik. Vizsgálatukban alkalmazták a klasszikus olvasási terjedelem feladatot, a mondat-szám terjedelem feladatot (mondatok elolvasása, számok megjegyzése), a mủvelet-szóterjedelem feladatot (matematikai művelet megoldása, szavak megjegyzése) és a művelet-számterjedelem feladatot (matematikai művelet megoldása, számokra való emlékezés). Eredményeik szerint a jól olvasók több szóra és számra emlékeztek, függetlenül attól, hogy a másodlagos feladat olvasási vagy számolási készséget igényelt-e. Mind a négy típusú komplex terjedelmi feladat bejósolta az olvasási megértést, vagyis a nagyobb munkamemória-kapacitás független volt a 
háttérfeladat típusától. Vagyis úgy tűnik, a munkamemória kapacitása és a kognitív képességek közti korreláció nem területspecifikus.

Kane és munkatársai (2004) a munkamemória-kapacitás területáltalánosságának kérdését kutatva azzal a feltételezéssel éltek, hogy ha a munkamemóriakapacitás elsősorban területáltalános végrehajtó folyamatokat tükröz, akkor a verbális és téri munkamemória-kapacitás erősebben korrelál egymással, mint a verbális és téri rövid távú emlékezet feladatai, amelyek sokkal inkább területspecifikus készségeket igényelnek. Eredményeik megerősítették ezt a feltevést: a különböző területspecifikus munkamemória-feladatok közti korreláció nagyjából olyan mértékű volt, mint a rövid távú emlékezeti feladatoknál az azonos területhez tartozóké. A munkamemória-feladatok tehát elsősorban területáltalános, és csak másodsorban területspecifikus készségeket vizsgálnak, míg a rövid távú emlékezeti kapacitás épp fordított: elsősorban a területspecifikus tárolási komponenseket, és csak másodsorban a központi végrehajtó teljesítményét tükrözik.

Daneman és Carpenter úttörő kutatását követően későbbi vizsgálatok rámutattak, hogy a munkamemória kapacitása a szövegértésen kívül más kognitív képességekkel (nyelvi megértés, döntéshozatal stb.), vagy ha úgy tetszik, az intelligencia számos különféle aspektusával is korrelál. A legtöbb idevágó vizsgálatot fluid, nemverbális intelligenciát mérő tesztekkel végezték; a latens változók szintjén a fluid intelligencia és a munkamemória-kapacitás varianciájának nagyjából 50\%-a közös (Kane, Hambrick és Conway, 2005).

Mi állhat a két konstruktum kapcsolatának a hátterében? Engle és Kane (2004) szerint a munkamemória kapacitását mérő feladatok kritikus aspektusa a figyelem kontrolljának képessége. Számos eredmény szól emellett; a magasabb munkamemória-kapacitás együtt jár a jobb teljesítménnyel a figyelmi gátlási vagy proaktív interferenciafeladatokban. Továbbá latens változó elemzést használó vizsgálatok is rámutattak, hogy a munkamemóriának elsősorban a figyelmi folyamatokért felelős végrehajtó komponense felelős az intelligenciával való korrelációért, ami megmagyarázza, hogy a munkamemória miért korrelál jobban az intelligenciával, mint a rövid távú emlékezet (Conway, Cowan, Bunting, Therriault és Minkoff, 2002; Engle, Tuholski, Laughlin és Conway, 1999).

Ugyanakkor a munkamemória és az intelligencia közti kapcsolat hátterében több különböző folyamat állhat: bár a transzformációs feladatok, az $\mathrm{N}$-vissza feladatok és a komplex terjedelemi feladatok mind korrelálnak a fluid intelligenciával, többszörös regresszióelemzés eredményei alapján kiderül, hogy a fluid intelligenciában lévő variancia különböző részeit magyarázzák (Conway és mtsai, 2011). Vagyis úgy tűnik, önmagában a végrehajtó figyelem sem tekinthető egységes rendszernek; ezt pedig idegtudományi vizsgálatok is alátámasztják (például Dreher és Berman, 2002; Robbins, 1996).

Mivel a munkamemóriához hasonlóan az intelligencia is számos komponensből áll, itt is felmerül a kérdés, hogy mi felelős a munkamemória-kapacitással való korrelációért? Ha különféle képességtesztek munkamemóriával és rövid távú emlékezettel való korrelációit összehasonlítjuk, akkor kiderül, hogy a munkamemóriának az egyszerű tároláson és előhíváson túli komponense (vagyis a végrehajtó komponens) elsősorban a fluid intelligenciával, majd a numerikus gondolkodással 
korrelál, a verbális képességekkel kevésbé, legkevésbé pedig a perceptuális sebességet vagy általános ismereteket mérő tesztekkel mutat kapcsolatot (Conway és Kovacs, 2013; Kovacs, 2010).

Úgy tűnik, hogy a munkamemória-kapacitást és a fluid intelligenciát mérő tesztek eredményeit egyaránt többszörös területáltalános kognitív mechanizmusok határozzák meg, a két konstruktum közötti korreláció pedig olyan területáltalános kognitív mechanizmusokból származik, amelyek a fluid intelligenciát és a munkamemória-kapacitást mérő feladatokban nyújtott teljesítményhez egyaránt szükségesek (Conway és Kovacs, 2015; Kovacs és Conway, kézirat). Ez az átfedés magyarázhatja, hogy a két konstruktum varianciájának nagyjából a fele közös. Az egymást átfedő pszichológiai folyamatok pedig végső soron egymást átfedő idegrendszeri mechanizmusokra vezethetők vissza; a fluid intelligencia és a munkamemória végrehajtó rendszere hasonló idegrendszeri - elsősorban prefrontális kérgi - korrelátumokkal rendelkezik.

A munkamemória-kapacitás a kognitív képességeken kívül az iskolai teljesítménnyel (utasításkövetés, jegyzetelés, írás, olvasás, érvelés stb.) is korrelál (Janacsek és mtsai, 2009). Tánczos Tímea és munkatársai (Tánczos, Janacsek és Németh, 2014) longitudinális vizsgálatukban felmértek bizonyos kognitív faktorokat az iskola kezdetekor (köztük a munkamemóriát és végrehajtó funkciókat), majd négy évvel később, és vizsgálták ezen faktorok bejósló hatását az iskolai teljesítményre. A végrehajtó funkcióknak fontos szerepe van a gondolatok tudatos kontrolljában és a viselkedés irányításában a távoli cél elérése érdekében, melyek az iskolai teljesítmény szempontjából meghatározó szerepet töltenek be. Vizsgálatukba 105 tipikus fejlődésủ gyereket vontak be. Tanulmányi eredményüket az év végi érdemjegyük mutatta magyar nyelv és irodalom, matematika, környezetismeret tárgyakban. Az eredmények szerint a tanulmányi teljesítmény szempontjából meghatározók a téri-vizuális munkamemória, a komplex terjedelmi, valamint a végrehajtó és nyelvi funkciókat mérő fluenciafeladatok.

\section{A MUNKAMEMÓRIA ÉLETKORI KÜLÖNBSÉGEI}

A munkamemória-feladatokban nyújtott teljesítmény az életkorral 15 éves korig nő, miközben az alapvető szerkezet azonos marad 6 éves kortól (Gathercole és mtsai, 2004). A fejlődést gyakran a jobb feldolgozási hatékonysággal magyarázzák, vagyis azzal, hogy a feldolgozás és a tárolás osztoznak a kapacitáson, és az életkorral a személyek a feldolgozáshoz szükséges forrásokból egyre többet tudnak átcsoportosítani a tárolásra, ami által a feldolgozás sebessége és a tárolási hatékonyság nő. Egy másik lehetséges magyarázat szerint viszont az életkorral a másodlagos feladat megoldási sebessége nő, így kevesebb késleltetés lesz pl. egy szólista tanulása és előhívása között, amely által javul a munkamemória-teljesítmény.

Gaillard és munkatársai (Gaillard, Barrouillet, Jarrold és Camos, 2011) szerint a munkamemória-terjedelem feladatokban nyújtott teljesítmény a terjedelmi feladat feldolgozásához szükséges időtől és a memóriatárak helyreállításához szükséges időtől függ. Az ezen tárak által tárolt és a feldolgozási feladat alatt elhalványult 
információ újraaktiválásához szükséges idő meghatározza a fenntartó mechanizmusok hatékonyságát. A szerzők szerint az idősebb gyerekek a tárolt emlékek reaktiválásában hatékonyabbak lehetnek, és ez eredményezi az életkori különbségeket a munkamemória-kapacitásban.

A fonológiai rövid távú emlékezet is nő az életkorral: az ismétlési készség 8-9 éves korig meredeken, majd 14 éves korig lassabban emelkedik. A munkamemóriakapacitás lassabb növekedést mutat, folyamatos meredekséggel körülbelül 16-17 éves korban éri el a maximumát. Egy magyar vizsgálatban 647, 4 és 89 év közötti személy vizsgálatával kimutatták, hogy a Hallási Mondatterjedelem Teszttel felmért munkamemória-kapacitásban gyermekkortól 17 éves korig meredek teljesítménynövekedés figyelhető meg, majd az elért teljesítmény felnőttkorban stagnál, és 45 éves korban kezdődik a teljesítmény hanyatlása (Janacsek és mtsai, 2009).

Az életkori változásokat tekintve jelen cikk szempontjából különösen érdekes az visszafelé terjedelem státusza. Mint említettük, a visszafelé terjedelmi feladatok komplexitás tekintetében az egyszerű és a komplex terjedelemi feladatok között állnak, ugyanakkor a transzformációs típusú munkamemória-feladatok kritériumainak megfelelnek. Ráadásul úgy tűnik, ez a kérdés az életkortól sem független: a visszafelé számterjedelmi feladat sokkal inkább korrelál a munkamemóriával, mint a rövid távú emlékezettel 8 éveseknél, ugyanakkor 21 éveseknél ennek épp a fordítottja figyelhető meg. Vagyis gyerekek esetében a visszafelé terjedelmi feladatok a munkamemória-kapacitás teljesen valid mérőeszközének tekinthetők, felnőtteknél pedig fogalmilag a komplex és a sima terjedelem között állnak (St. ClairThompson, 2010).

\section{A FELADATOK LEÍRÁSA}

Az eredetikhez hasonlóan a Corsi- és számterjedelmi feladatok online elérhetők (kognitiv.uni-eger.hu) és szabadon felhasználhatók. A hagyományos, laboratóriumi körülményeken kívül a feladatok online is felvehetők: a vizsgálati személyek az Inquisit Player lejátszó telepítését követően a számára elküldött közvetlen linken keresztül is megoldhatják a feladatokat, amelyek - választhatóan - vagy a Millisecond oldalán, vagy saját szerveren futnak; a rendszer az eredményeket oda menti, ahol a feladatok futnak.

A feladatok az Inquisit kísérleti szoftver () Millisecond Software) alatt futnak („.iqx” formátumúak). Az alábbiakban ismertetjük az egyes feladatok leírását, valamint az összesített eredményfájlban (,.iqdat”) található mutatókat. Az összesített eredményfájlon kívül a feladatok elvégzését követően az egyes személyek adatait tartalmazó nyers eredményfájl is rendelkezésre áll, amelyben egyesével megtalálható valamennyi inger a személyek összes válaszával, másodperces pontossággal naplózva. Az N-vissza feladat esetében összesített eredményfájl nem áll rendelkezésre, kizárólag az összes választ tartalmazó táblázat (lásd lent). 
Corsi-feladat (odafelé) ${ }^{1}$ :

Leirás. A Corsi-feladat online változata a téri rövid távú emlékezetet méri. A feladatmegoldás során helyeket kell megjegyezni. ${ }^{2}$ A képernyőn kilenc kék színű négyzet látható fekete háttérrel, ezek közül minden próba során egyesével villan fel néhány. A felvillanó négyzetek színe sárga, az egyes négyzetek 1 másodpercenként villannak fel úgy, hogy a felvillanás 750 ms-ig tart, a következő felvillanásig pedig $250 \mathrm{~ms}$ telik el. A vizsgálati személynek fel kell idéznie a felvillanások sorrendjét, és az eredetivel azonos sorrendben kattintani a négyzetekre. A feladatnak nincs gyakorló része, ugyanakkor nagyon könnyü szinten, két felvillanó négyzettel kezdődik. Minden sorozat kétszer szerepel, vagyis kétszer villan fel két, kétszer három négyzet, és így tovább. Az egyes válaszok után a személy visszajelzést kap arról, hogy a válasza helyes-e. Amennyiben az adott hosszúságú két próba legalább egyikét helyesen megoldja, a mérés eggyel hosszabb próbával folytatódik. Amennyiben az adott hosszúságnál mindkét próbára helytelen választ ad, a feladat leáll. A leghosszabb lehetséges sorozat 16 felvillanásból áll.

Eredmény. A feladat a következő változókat adja eredményül:

'completed': az 1-es érték befejezett, a 0-s megszakított feladatot jelöl.

'ncorrecttotal': a feladat során a hibátlanul megoldott sorozatok száma.

'blockspan': a terjedelem, vagyis a leghosszabb helyesen megoldott sorozat hossza.

'totalscore': Kessels, van Zandvoort, Postma, Kappelle, Jaap és de Haan (2000) által bevezetett összpontszám, az 'ncorrecttotal' és a 'blockspan' szorzata.

\section{Corsi-feladat (visszafelé):}

Leírás. A feladat elrendezése megegyezik az odafelé mért Corsi-feladattal, azzal a különbséggel, hogy itt fordított sorrendben kell a négyzetekre kattintani, mint ahogy felvillantak, illetve itt 14 , nem pedig 16 felvillanásból áll a lehetséges leghosszabb sorozat.

Eredmény. A feladat ugyanazokat a változókat adja eredményül, mint az odafelé mért Corsi-feladat.

\section{Számterjedelem (oda- és visszafelé) $)^{3}$}

Leirás. A kétféle számterjedelmi feladat azonos scriptről fut. A feladatok Woods és munkatársai (2011) első kísérletének elrendezését követik. A feladat mindkét vál-

1 Mindkét Corsi-feladat eredeti változatát David Nitz készítette, (C) Millisecond Software.

${ }^{2}$ Az eredeti Corsi-feladatban (Corsi, 1972) egy kilenc, lapra rögzített kockából álló eszközt használnak, amelynek a számozása csak a vizsgálatvezető szemszögéből látható. A vizsgálatvezető az előre rögzített sorrendben megérinti a kockákat, majd a sorozat befejeztével a vizsgálati személynek is meg kell érintenie az egyes kockákat az eredeti sorrendben. Az eredeti változat tehát tartalmaz egy téri komponenst is, míg a számítógépes változat a képernyő jellegénél fogva kétdimenziós.

3 A feladat eredeti változatát Katja Borchert készítette, (C) Millisecond Software. 
tozatában számok villannak fel a képernyő közepén, másodpercenként egy. Az első próbát megelőzően egy gyakorló feladatot kell megoldani, az odafelé változatban három, a visszafelé változatban két számjeggyel. A próba eredményéről a személy visszajelzést kap, ugyanakkor a feladat a próbafeladatra adott válasz helyességétől függetlenül elindul. Az éles feladat a próbafeladattal megegyező számú számjeggyel indul.

Az első szám bemutatását megelőzően és az utolsó szám eltűnését követően egy piros pont jelenik meg a képernyő közepén. A második piros pont eltűnését követően egy szövegdoboz jön fel, amelybe a személynek be kell írnia a látott számokat, az odafelé számterjedelmi feladatban az eredeti, a visszafelé számterjedelmi feladatban pedig fordított sorrendben. A szövegdobozba a program legfeljebb annyi számjegyet enged beírni, amennyi felvillant a próba során. Ha a válasz helyes, a számjegyek sorozata eggyel nő. Amennyiben helytelen, megismétlődik az adott hosszúságú sorozat. Két, egymást követő hiba után a hosszúság eggyel csökken, de nem mehet az odafelé feladatban három, a visszafelé feladatban kettő alá. A feladat összesen 14 próbából áll. Az elérhető leghosszabb számsorozat 16 az előrefelé számterjedelmi, és 15 a visszafelé számterjedelmi feladatban.

A feladatban kizárólag 1 és 9 közti számok szerepelnek. A sorozatokban az első 9, valamint a 10. és 16. közti számjegyek nem ismétlődnek, és a 10. számjegy soha nem azonos a 9. számjeggyel. Továbbá nincsenek ismétlődő számsorozatok, és egymást követő három számjegy esetén soha nem egyenlő a távolság.

Eredmény. A feladat a következő változókat adja eredményül:

'completed': az 1-es érték befejezett, a 0-s megszakított feladatot jelöl.

'TE_ML': a leghosszabb, két egymást követő hibázás előtt helyesen felidézett számsorozat hossza. Ez a számterjedelem hagyományos mutatója.

'TE_TT': a két hibázás előtt, vagyis a 'TE_ML' rögzítése elött megoldott próbák száma. A válaszadás konzisztenciáját tükrözi. A feladat megkezdése előtti értéke -1 .

'ML': a leghosszabb számsorozat, amelyet a személy a 14 próba során helyesen felidézett. A feladat megkezdése előtti értéke 0.

'MS': az a terjedelem, amelyet a személy a 14 próbán nyújtott összteljesítménye alapján várhatóan az esetek 50\%-ában helyesen idéz fel. A feladat megkezdése elötti értéke 0 .

A 'completed' változót leszámítva, amely a teljes feladatra vonatkozik, a feladat kétféle változata ugyanazokat a változókat adja eredményül. A változó előtt 'f, illetve 'b' jelzi, hogy a feladat melyik változatára vonatkozik (fTE_ML, bTE_TT stb.).

\section{$N$-vissza feladat}

Leírás. Az „N-vissza” feladatban minden soron következő bemutatott ingernél el kellett dönteni, hogy azonos-e az N-lépéssel, például az 1-gyel, 2-vel, 3-mal vagy 4-gyel azelőtt bemutatott ingerrel (1.ábra). 


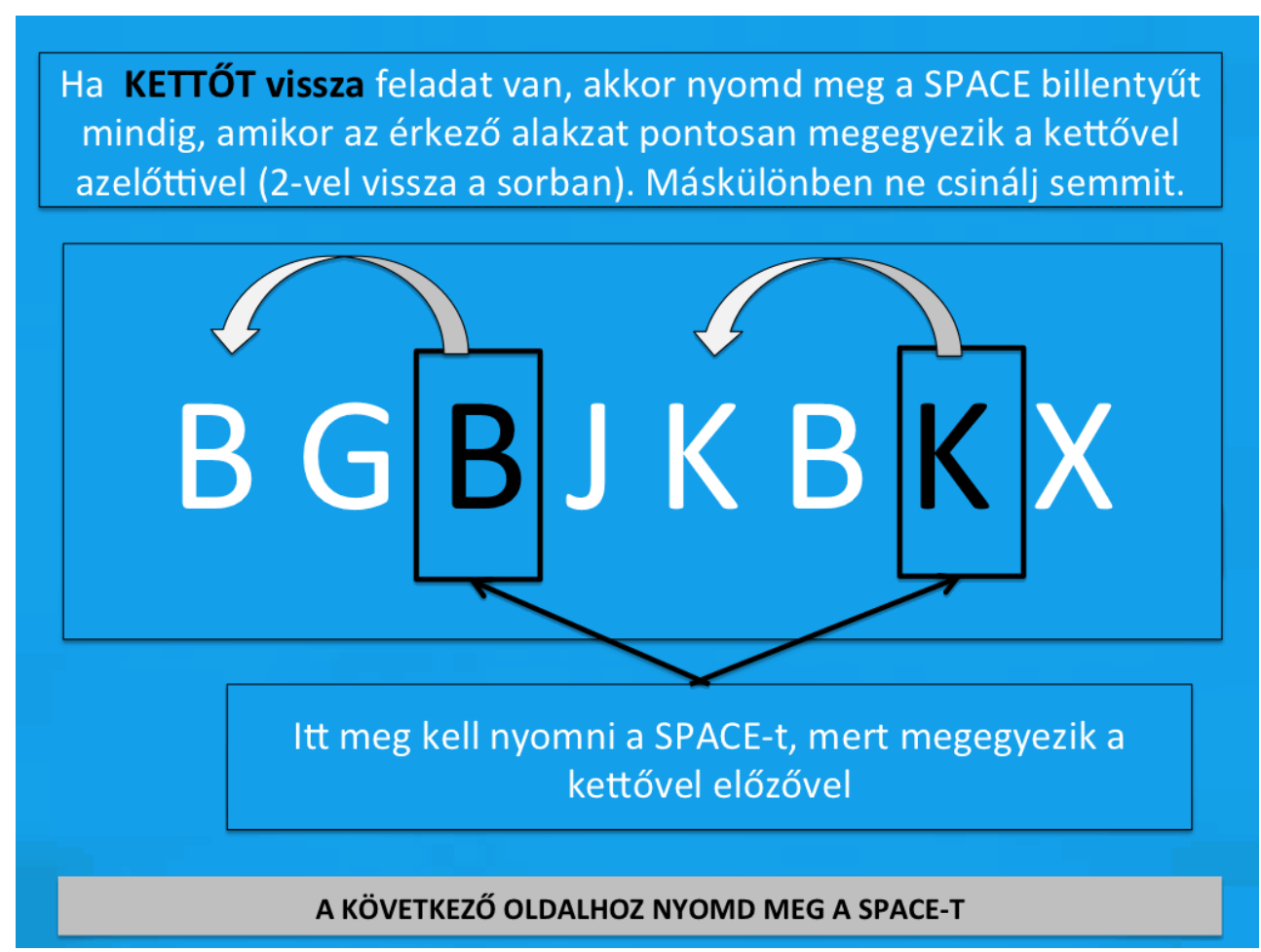

1. ábra. N-vissza feladat instrukciós képernyője

Az elrendezést Kövi, Marton és Rózsa (publikálás alatt, a feladat részletes elrendezését lásd itt) alakították ki, ${ }^{4}$ az elrendezés alapját Kane, Conway, Miura és Colflesh (2007) vizsgálati elrendezése adta. Az ingerek: B, F, K, H, M, Q, R, X. Az $\mathrm{N}$ nulla és négy között változik, vagyis a sorozat egy 0 -vissza feladattal kezdődik gyakorlásként, itt egyszerüen az X-ek megjelenésekor kell jelezni. Ezt követi az 1vissza feladat, amelyet egy gyakorló blokk után egy „éles” követ, majd sorrendben a 2, 3 és 4-vissza blokkok, amelyek mindegyike egy gyakorló és két „éles” blokkból áll. Összesen tehát 12 blokkból áll a feladat. Az 1-vissza feladattól kezdve a próbákban úgynevezett „hurok” (lure) próbák is szerepelnek. Itt olyan, $\mathrm{n}+1$. és $\mathrm{n}-1$. helyen szereplő „zavaró” ingerekről van szó, amelyek proaktív, illetve retroaktív interferenciát váltanak ki, pl. a 3-vissza feladatnál Q H M F Q, illetve Q H Q stb. Egy blokkon belül minden betű 6-szor tűnik fel, és minden betű egyszer szerepel célingerként.

${ }^{4}$ Az N-vissza feladat itt ismertetett változata a MATEHETSZ (Magyar Tehetségsegítő Szervezetek Szövetsége) megbízásából, a „Magyar Templeton program, Kivételes kognitív tehetségek támogatása” projekt keretein belül készült. 
1. táblázat. A N-vissza feladat teljes elrendezése

\begin{tabular}{|c|c|c|c|c|c|c|c|c|c|c|c|}
\hline & \multirow{2}{*}{\multicolumn{8}{|c|}{$\begin{array}{l}\text { Az egy blokkon belül szereplő betűk előfordu- } \\
\text { lási száma (hányszor jelenik meg az adott betű } \\
\text { egy blokkban) }\end{array}$}} & \multicolumn{2}{|c|}{$\begin{array}{l}\text { Az egy blokkon belül } \\
\text { szereplő elemek }\end{array}$} \\
\hline & & & & & & & & & & Itemek & élingerek \\
\hline & & B & $\mathrm{F}$ & K & $\mathrm{H}$ & M & Q & $\mathrm{R}$ & $\mathrm{X}$ & & \\
\hline 0-vissza & 1 & 3 & 3 & 3 & 3 & 3 & 3 & 3 & 8 & $29 \mathrm{db}$ & $8 \mathrm{db}$ \\
\hline 1-vissza & $\begin{array}{l}1+ \\
1 \text { gyakorló }\end{array}$ & 4 & 4 & 4 & 4 & 4 & 4 & 4 & 4 & $32 \mathrm{db}$ & $8 \mathrm{db}$ \\
\hline 2-vissza & $\begin{array}{l}2+ \\
1 \text { gyakorló }\end{array}$ & 6 & 6 & 6 & 6 & 6 & 6 & 6 & 6 & $48 \mathrm{db}$ & $8 \mathrm{db}$ \\
\hline 3-vissza & $\begin{array}{l}2+ \\
1 \text { gyakorló }\end{array}$ & 6 & 6 & 6 & 6 & 6 & 6 & 6 & 6 & $48 \mathrm{db}$ & $8 \mathrm{db}$ \\
\hline 4-vissza & $\begin{array}{l}2+ \\
1 \text { gyakorló }\end{array}$ & 6 & 6 & 6 & 6 & 6 & 6 & 6 & 6 & $48 \mathrm{db}$ & $8 \mathrm{db}$ \\
\hline
\end{tabular}

Eredmény. Az N-vissza feladat nem ad összesített eredményt, ugyanakkor minden h5 személy esetében rögzíti valamennyi választ, a táblázat alapján pedig minden egyes válasz esetében eldönthető, hogy találat, kihagyás, helyes elutasítás vagy téves riasztás történt, tetszés szerint a különböző hosszúságú blokkokra vagy összesítve. Az „Eredmények” részben az összes blokk eredménye alapján közöljük a találat és a téves riasztás különbségére vonatkozó normatív adatokat.

\section{A SZTENDERDIZÁLÁSHOZ HASZNÁLT MINTA LEÍRÁSA}

A vizsgálatban a következő egri és Eger környéki iskolák vettek részt: Pásztorvölgyi Általános Iskola és Gimnázium, Eszterházy Károly Főiskola Gyakorló Általános Iskola, Közép-, Alapfokú Művészeti Iskola és Pedagógiai Intézet, Hunyadi Mátyás Általános Iskola, Kemény Ferenc Sportiskola és Általános Iskola, Verpeléti Arany János Általános Iskola és Reményi Ede Alapfokú Művészeti Iskola, Kerecsendi Magyary Károly Általános Iskola, Dobó István Gimnázium, Szilágyi Erzsébet Gimnázium.

A vizsgálatban az iskolák 4., 8. és 12. évfolyamai vettek részt, az első csoportba tartozó diákok 9-11, a másodikba tartozók 13-15, a harmadikba tartozók pedig 17-19 évesek voltak. A teljes minta életkori átlaga 13,88 év (szórás: 3,29), az 1001 főből 529 (52,8\%) lány. A 4. évfolyamos csoportba 319-en tartoztak, ebből 143 $(44,8 \%)$ lány, az életkori átlag itt 9,81 év (szórás: 0,51). A 8. évfolyamos csoportba 337 diák tartozott, közülük 179 (53,1\%) lány, az életkori átlag itt 13,76 év (szórás: 0,48). Végül a 12. évfolyamos csoportba 345 fő tartozott, ebből 207 fó (60\%) lány, az életkori átlag pedig 17,77 év (szórás: 0,69). 


\section{EREDMÉNYEK}

Az egyes mutatók leíró statisztikai eredményeit a 2-4. táblázat tartalmazza. Ahogy várható, az egyes feladatokban elért átlagok az életkor előrehaladtával emelkednek. Meglepő eredmény ugyanakkor, hogy a 10 és 14 éves korosztályban a Corsiteszt visszafelé mért változatán elért eredmény jobb, mint az odafelé felvett változaton. Ennek az lehet az oka, hogy a Corsi-feladat visszafelé felvett változata - a számterjedelemmel szemben - nem sokkal nehezebb az odafelé felvett változatnál, és mivel a két feladatot minden esetben egymás után oldották meg, a gyakorlási hatás felülmúlhatta a nehézségbeli különbséget. Ezért az alábbiakban közölt normák értelmezésekor is fontos figyelembe venni a sorrendet. Más szavakkal: míg az odafelé Corsi esetében számított percentilis értékek önmagukban is érvényesek, a visszafelé felvett változat normája módszertani szempontból csak akkor érvényes, ha közvetlenül az odafelé felvett Corsi után töltik ki a vizsgálati személyek.

2. táblázat. A feladatok leíró statisztikai mutatói 10 éveseknél

\begin{tabular}{|l|l|c|c|c|}
\hline \multicolumn{1}{|c|}{10 évesek } & \multicolumn{1}{|c|}{ Változó } & $\mathrm{N}$ & Átlag & Szórás \\
\hline Corsi odafelé & 'totalscore' & 276 & 32,26 & 13,53 \\
\hline Corsi visszafelé & 'totalscore' & 232 & 35,29 & 16,29 \\
\hline \multirow{2}{*}{$\begin{array}{l}\text { Számterjedelem } \\
\text { odafelé }\end{array}$} & 'fTE_ML' & 315 & 4,66 & 1,12 \\
\cline { 2 - 5 } & 'fML' & 313 & 5,22 & 0,97 \\
\cline { 2 - 5 } & 'fMS' & 314 & 4,71 & 0,86 \\
\hline \multirow{2}{*}{$\begin{array}{l}\text { Számterjedelem } \\
\text { visszafelé }\end{array}$} & 'bTE_ML' & 314 & 3,69 & 1,12 \\
\cline { 2 - 5 } & 'bML' & 307 & 4,31 & 0,97 \\
\cline { 2 - 5 } & 'bMS' & 310 & 3,73 & 0,94 \\
\hline \multirow{2}{*}{ N-vissza } & Találat & 302 & 0,631 & 0,17 \\
\cline { 2 - 5 } & Téves riasztás & 302 & 0,334 & 0,22 \\
\cline { 2 - 5 } & Találat - téves riasztás & & & 0,16 \\
\hline
\end{tabular}

3. táblázat. A feladatok leíró statisztikai mutatói 14 éveseknél

\begin{tabular}{|l|l|c|c|c|}
\hline \multicolumn{1}{|c|}{14 évesek } & \multicolumn{1}{c|}{ Változó } & N & Átlag & Szórás \\
\hline Corsi odafelé & 'totalscore' & 304 & 46,25 & 16,98 \\
\hline Corsi visszafelé & 'totalscore' & 283 & 49,03 & 16,41 \\
\hline \multirow{2}{*}{$\begin{array}{l}\text { Számterjedelem } \\
\text { odafelé }\end{array}$} & 'fTE_ML' & 334 & 5,6 & 1,08 \\
\cline { 2 - 5 } & 'fML' & 333 & 6,21 & 1,05 \\
\cline { 2 - 5 } & 'fMS' & 334 & 5,75 & 0,92 \\
\hline \multirow{2}{*}{$\begin{array}{l}\text { Számterjedelem } \\
\text { visszafelé }\end{array}$} & 'bTE_ML' & 334 & 4,85 & 1,29 \\
\cline { 2 - 5 } & 'bML' & 334 & 5,55 & 1,18 \\
\cline { 2 - 5 } & 'bMS' & 334 & 5,01 & 1,14 \\
\hline \multirow{2}{*}{\begin{tabular}{l} 
N-vissza \\
\cline { 2 - 5 }
\end{tabular}} & Találat & 331 & 0,669 & 0,12 \\
\cline { 2 - 5 } & Téves riasztás & 331 & 0,205 & 0,19 \\
\cline { 2 - 5 } & Találat - téves riasztás & 364 & 0,17 \\
\hline
\end{tabular}


4. táblázat. A feladatok leíró statisztikai mutatói 18 éveseknél

\begin{tabular}{|l|l|c|c|c|}
\hline \multicolumn{1}{|c|}{18 évesek } & \multicolumn{1}{|c|}{ Változó } & $\mathrm{N}$ & Átlag & Szórás \\
\hline Corsi odafelé & 'totalscore' & 327 & 54,65 & 19,93 \\
\hline Corsi visszafelé & 'totalscore' & 307 & 51,7 & 13,95 \\
\hline \multirow{2}{*}{$\begin{array}{l}\text { Számterjedelem } \\
\text { odafelé }\end{array}$} & 'fTE_ML' & 344 & 6,36 & 1,48 \\
\cline { 2 - 5 } & 'fML' & 344 & 7,04 & 1,32 \\
\cline { 2 - 5 } & 'fMS' & 344 & 6,53 & 1,32 \\
\hline \multirow{2}{*}{$\begin{array}{l}\text { Számterjedelem } \\
\text { visszafelé }\end{array}$} & 'bTE_ML' & 344 & 5,92 & 1,79 \\
\cline { 2 - 5 } & 'bML' & 344 & 6,66 & 1,58 \\
\cline { 2 - 5 } & 'bMS' & 282 & 6,14 & 1,63 \\
\hline \multirow{2}{*}{ N-vissza } & Találat & 282 & 0,693 & 0,12 \\
\cline { 2 - 5 } & Téves riasztás & 282 & 0,166 & 0,19 \\
\cline { 2 - 5 } & Találat - téves riasztás & & & 0,18 \\
\hline
\end{tabular}

Az 5-9. táblázat tartalmazza a feladatok normatív adatait az egyes korosztályokban a fontosabb centilis értékekkel. A táblázatok alapján a különböző képességtartományokban (például kvartiliseknél) külön is összehasonlítható az egyes feladatokon nyújtott teljesítmény. Végül a 10. táblázat mutatja a feladatok közti korrelációkat a teljes mintán.

5. táblázat. A Corsi odafelé felvett változatának normatáblázata

\begin{tabular}{|c|c|c|c|c|c|c|c|c|}
\hline \multirow{2}{*}{\multicolumn{2}{|c|}{$\begin{array}{l}\text { Corsi odafelé, } \\
\text { 'totalscore' }\end{array}$}} & \multicolumn{7}{|c|}{ Percentilis értékek } \\
\hline & & 5 & 10 & 25 & 50 & 75 & 90 & 95 \\
\hline \multirow{3}{*}{$\begin{array}{l}\ddot{0} \\
\frac{0}{0} \\
\frac{\ddot{U}}{\Delta I}\end{array}$} & 10 év & 6 & 12 & 24 & 35 & 40 & 48 & 54 \\
\hline & 14 év & 21 & 30 & 35 & 42 & 54 & 70 & 77 \\
\hline & 18 év & 30 & 35 & 40 & 54 & 70 & 77 & 96 \\
\hline
\end{tabular}

6. táblázat. A Corsi visszafelé felvett változatának normatáblázata

\begin{tabular}{|c|c|c|c|c|c|c|c|c|}
\hline \multirow{2}{*}{\multicolumn{2}{|c|}{$\begin{array}{l}\text { Corsi visszafelé, } \\
\text { 'totalscore' }\end{array}$}} & \multicolumn{7}{|c|}{ Percentilis értékek } \\
\hline & & 5 & 10 & 25 & 50 & 75 & 90 & 95 \\
\hline \multirow{3}{*}{$\begin{array}{l}\ddot{0} \\
\frac{0}{ \pm} \\
\frac{0}{\mid I I}\end{array}$} & 10 év & 4 & 12 & 24 & 35 & 48 & 54 & 60 \\
\hline & 14 év & 20 & 24 & 40 & 51 & 60 & 70 & 77 \\
\hline & 18 év & 24 & 35 & 48 & 54 & 60 & 70 & 77 \\
\hline
\end{tabular}


7. táblázat. A számterjedelem odafelé felvett változatának normatáblázata

\begin{tabular}{|c|c|c|c|c|c|c|c|c|}
\hline \multirow{2}{*}{\multicolumn{2}{|c|}{\begin{tabular}{|c|} 
Számterjedelem \\
odafelé, 'fMS'
\end{tabular}}} & \multicolumn{7}{|c|}{ Percentilis értékek } \\
\hline & & 5 & 10 & 25 & 50 & 75 & 90 & 95 \\
\hline \multirow{3}{*}{$\frac{0}{\frac{0}{v}}$} & 10 év & 3,24 & 3,61 & 4,17 & 4,7 & 5,2 & 5,82 & 6,18 \\
\hline & 14 év & 4,5 & 4,7 & 5,17 & 5,64 & 6,25 & 6,9 & 7,39 \\
\hline & 18 év & 4,88 & 5,17 & 5,75 & 6,32 & 7,15 & 8 & 8,5 \\
\hline
\end{tabular}

8. táblázat. A számterjedelem visszafelé felvett változatának normatáblázata

\begin{tabular}{|c|c|c|c|c|c|c|c|c|}
\hline \multirow{2}{*}{\multicolumn{2}{|c|}{$\begin{array}{l}\text { Számterjedelem } \\
\text { visszafelé, 'bMS' }\end{array}$}} & \multicolumn{7}{|c|}{ Percentilis értékek } \\
\hline & & 5 & 10 & 25 & 50 & 75 & 90 & 95 \\
\hline \multirow{3}{*}{$\frac{\tilde{0}}{\frac{\tilde{d}}{v|c|}}$} & 10 év & 2,13 & 2,6 & 3,13 & 3,72 & 4,38 & 4,83 & 5,22 \\
\hline & 14 év & 3,27 & 3,65 & 4,17 & 4,98 & 5,77 & 6,50 & 7,08 \\
\hline & 18 év & 4 & 4,43 & 5,15 & 5,92 & 6,9 & 7,77 & 8,46 \\
\hline
\end{tabular}

9. táblázat. Az N-vissza feladat normatáblázata

\begin{tabular}{|c|c|c|c|c|c|c|c|c|}
\hline \multirow{2}{*}{\multicolumn{2}{|c|}{$\begin{array}{c}\text { N-vissza, } \\
\text { találat - téves } \\
\text { riasztás }\end{array}$}} & \multicolumn{7}{|c|}{ Percentilis értékek } \\
\hline & & 5 & 10 & 25 & 50 & 75 & 90 & 95 \\
\hline \multirow{3}{*}{$\begin{array}{c}\ddot{0} \\
\frac{0}{0} \\
\frac{0}{ \pm}\end{array}$} & 10 év & 0,014 & 0,077 & 0,18 & 0,305 & 0,43 & 0,502 & 0,544 \\
\hline & 14 év & 0,178 & 0,233 & 0,349 & 0,479 & 0,578 & 0,677 & 0,736 \\
\hline & 18 év & 0,219 & 0,280 & 0,43 & 0,535 & 0,645 & 0,751 & 0,81 \\
\hline
\end{tabular}

10. táblázat. A feladatok közti korrelációk.

Az átló alatt az eredeti, az átló felett az életkorra kontrollált parciális korrelációk láthatók

\begin{tabular}{|l|c|c|c|c|c|}
\hline & $\begin{array}{c}\text { Corsi odafelé, } \\
\text { 'totalscore' }\end{array}$ & $\begin{array}{c}\text { Corsi visszafelé, } \\
\text { 'totalscore' }\end{array}$ & $\begin{array}{c}\text { Számterjede- } \\
\text { lem odafelé, } \\
\text { 'fMS' }\end{array}$ & $\begin{array}{c}\text { Számterjede- } \\
\text { lem visszafelé, } \\
\text { 'bMS' }\end{array}$ & $\begin{array}{c}\text { N-vissza, } \\
\text { találat - téves } \\
\text { riasztás }\end{array}$ \\
\hline $\begin{array}{l}\text { Corsi odafelé, } \\
\text { 'totalscore' }\end{array}$ & 0,291 & 0,201 & 0,165 & 0,229 \\
\hline $\begin{array}{l}\text { Corsi visszafelé, } \\
\text { 'totalscore' }\end{array}$ & 0,392 & 0,401 & 0,228 & 0,230 & 0,225 \\
\hline $\begin{array}{l}\text { Számterjedelem } \\
\text { odafelé, 'fMS' }\end{array}$ & 0,418 & 0,407 & 0,736 & 0,589 & 0,206 \\
\hline $\begin{array}{l}\text { Számterjedelem } \\
\text { visszafelé, 'bMS' }\end{array}$ & 0,397 & 0,372 & 0,455 & 0,472 & 0,210 \\
\hline $\begin{array}{l}\text { N-vissza, } \\
\text { találat - téves } \\
\text { riasztás }\end{array}$ & 0,385 & & & \\
\hline
\end{tabular}

Valamennyi korreláció esetében $p<0,001$ 


\section{ÖSSZEFOGLALÁS}

Tanulmányunkban bemutattunk öt, az emlékezeti terjedelem (a rövid távú emlékezet és a munkamemória) mérésére alkalmas feladat magyar változatát. Az $\mathrm{N}$-vissza feladatot leszámítva, amely saját fejlesztés, a feladatok ingyenesen felhasználható angol nyelvű emlékezeti feladatok magyar adaptációi. A feladatok mind laboratóriumi körülmények között, mind online alkalmasak az emlékezeti terjedelem mérésére. A feladatok a szerzők reményei szerint érdemben hozzájárulnak a magyar nyelven elérhető, és különösen az Interneten keresztül felvehető kísérleti pszichológiai eszközök elérhetőségéhez.

\section{IRODALOM}

Anderson, M. C., Baddeley, A. D. és Eysenck, M. W. (2010). Emlékezet. Budapest: Akadémiai Kiadó.

Atkinson, R. C., \& Shiffrin, R. M. (1968). Human Memory: A Proposed System and its Control Processes. Psychology of Learning and Motivation, 2, 89-195

Baddeley, A. D. (1992). Working memory. Science, 255(5044), 556-559.

Baddeley, A. D., \& Hitch, G. (1974). Working Memory. Psychology of Learning and Motivation, 8, 47-89.

Case, R., Kurland, D. M., \& Goldberg, J. (1982). Operational efficiency and the growth of short-term memory span. Journal of Experimental Child Psychology, 33(3), 386-404.

Conway, A. R. A., Cowan, N., Bunting, M. F., Therriault, D. J., \& Minkoff, S. R. (2002). A latent variable analysis of working memory capacity, short-term memory capacity, processing speed, and general fluid intelligence. Intelligence, 30(2), 163-183.

Conway, A. R. A., Kane, M. J., Bunting, M. F., Hambrick, D. Z., Wilhelm, O., \& Engle, R. W. (2005). Working memory span tasks: A methodological review and user's guide. Psychonomic Bulletin \& Review, 12 (5), 769-786.

Conway, A. R. A., \& Kovacs, K. (2013). Individual Differences in Intelligence and Working Memory. Psychology of Learning and Motivation, 58, 233-270.

Conway, A. R. A., \& Kovacs, K. (2015). New and emerging models of human intelligence. Wiley Interdisciplinary Reviews. Cognitive Science, 6 (5), 419-426.

Conway, A. R. A., Macnamara, B., Getz, S., \& Engel de Abreu, P. (2011). Working memory and fluid intelligence: A multi-mechanism view. In R. Sternberg, \& S. Kaufman (Eds.), Cambridge Handbook of Intelligence (pp. 394-418). New York: Cambridge University Press.

Corsi, P. M. (1972). Human memory and the medial temporal region of the brain. Dissertation Abstracts International, 34, 819B.

Cowan, N. (1999). An embedded-processes model of working memory. In A. Miyake, \& P. Shah (Eds.), Models of Working Memory (pp. 62-101). Cambridge: Cambridge University Press.

Cowan, N. (2001). The magical number 4 in short-term memory: A reconsideration of mental storage capacity. Behavioral and Brain Sciences, 24, 87-105.

Cowan, N., Saults, J. S., \& Clark, K. M. (2015). Exploring age differences in visual working memory capacity: is there a contribution of memory for configuration? Journal of Experimental Child Psychology, 135, 72-85. 
Daneman, M., \& Carpenter, P. A. (1980). Individual differences in working memory and reading. Journal of Verbal Learning and Verbal Behavior, 19(4), 450-466.

Dreher, J.-C., \& Berman, K. F. (2002). Fractionating the neural substrate of cognitive control processes. Proceedings of the National Academy of Sciences of the United States of America, 99, 14595-14600.

Engle, R. W., \& Kane, M. J. (2004). Executive attention, working memory capacity, and a two-factor theory of cognitive control. The Psychology of Learning and Motivation, 44, 145199.

Engle, R. W., Tuholski, S. W., Laughlin, J. E., \& Conway, A. R. A. (1999). Working memory, short-term memory, and general fluid intelligence: a latent-variable approach. Journal of Experimental Psychology. General, 128(3), 309-331.

Ericsson, K. A., \& Kintsch, W. (1995). Long-term working memory. Psychological Review 102(2), 211-245.

Gaillard, V., Barrouillet, P., Jarrold, C., \& Camos, V. (2011). Developmental differences in working memory: Where do they come from? Journal of Experimental Child Psychology, 110(3), 469-479.

Gathercole, S. E., Pickering, S. J., Ambridge, B., \& Wearing, H. (2004). The structure of working memory from 4 to 15 years of age. Developmental Psychology 40(2), 177-190.

Gold, J. M., Carpenter, C., Randolph, C., Goldberg, T. E., \& Weinberger, D. R. (1997). Auditory Working Memory and wisconsin card sorting test performance in schizophrenia. Archives of General Psychiatry, 54, 159-165.

Janacsek K., Tánczos T., Mészáros T. és Németh D. (2009). A munkamemória új magyar nyelvű neuropszichológiai mérőeljárása: a Hallási Mondatterjedelem Teszt (HMT). Magyar Pszichológiai Szemle, 64(2), 385-406.

Kane, M. J., Conway, A. R. A., Miura, T. K., \& Colflesh, G. J. H. (2007). Working memory, attention control, and the N-back task: a question of construct validity. Journal of Experimental Psychology. Learning, Memory, and Cognition, 33(3), 615-622.

Kane, M. J., Hambrick, D. Z., \& Conway, A. R. A. (2005). Working memory capacity and fluid intelligence are strongly related constructs: comment on Ackerman, Beier, and Boyle. Psychological Bulletin, 131, 66-71.

Kessels, R. P. C., van Zandvoort, M. J. E., Postma, A., Kappelle, J. L., \& de Haan, E. H. F. (2000). The Corsi Block-Tapping Task: Standardization and Normative Data. Applied Neuropsychology, 7 (February 2015), 252-258.

Kovacs, K. (2010). A component process account of the general factor of intelligence. Unpublished $\mathrm{PhD}$ thesis. University of Cambridge.

Kovacs, K., Rozsa, S., Ko, N., Meszaros, A., Mlinko, R., Kuncz, E., Nagyne Rez, I., \& Lanyine Engelmayer, A. (kézirat). Forward and backward digit span measure different cognitive abilities.

Németh D., Racsmány M., Kónya A. és Pléh Cs. (2001). A munkamemória-kapacitás mérőeljárásai és jelentőségük a neuropszichológiai diagnosztikában. Magyar Pszichológiai Szemle, 55(4), 403-416.

Oberauer, K., \& Hein, L. (2012). Attention to Information in Working Memory. Current Directions in Psychological Science, 21(3), 164-169.

Robbins, T. W. (1996). Dissociating executive functions of the prefrontal cortex. Philosophical Transactions of the Royal Society of London. Series B, Biological Sciences, 351, 1463-1470; discussion 1470-1471. 
St. Clair-Thompson, H. L. (2010). Backwards digit recall: A measure of short-term memory or working memory? European Journal of Cognitive Psychology (September 2011), 37-41.

Tánczos T., Janacsek K. és Németh D. (2014). A munkamemória és a végrehajtó funkciók kapcsolata az iskolai teljesítménnyel. Alkalmazott Pszichológia, 14(2), 55-75.

Turner, M. L., \& Engle, R. W. (1989). Is working memory capacity task dependent? Journal of Memory and Language, 28(2), 127-154.

Woods, D. L., Kishiyamaa, M. M., Lund, E. W., Herron, T. J., Edwards, B., Poliva, O., ... Reed, B. (2011). Improving digit span assessment of short-term verbal memory. Journal of Clinical and Experimental Neuropsychology, 33(1), 101-111.

\title{
THE ONLINE MEASUREMENT OF SHORT-TERM MEMORY AND WORKING MEMORY: CORSI, DIGIT SPAN AND N BACK
}

\author{
KOVÁCS, KRISTÓF - FARAGÓ, BOGLÁRKA - KÖVI, ZSUZSANNA - \\ RÓZSA, SÁNDOR - DÁVID, MÁRIA
}

\begin{abstract}
A number of different tasks have been developed to measure short-term memory and working memory, from digit span through complex span to $\mathrm{N}$-back. This paper reviews theoretical and methodological issues surrounding the measurement of memory span; discussing the domain-generality of working memory capacity, its relation to fluid intelligence and school achievement, and age differences. We present the Hungarian version of five tasks that measure memory span and can be used both in a laboratory setting and online: Corsi and digit span (both forward and backward), and the N-back task. The tasks were administered to a sample of approx. 1000, consisting of three cohorts (10, 14, and 18 year olds). We present age differences in performance, the correlation between the tasks, and the norm tables with percentile scores.
\end{abstract}

Key words: $\quad$ short-term memory, working memory, memory span, fluid intelligence, online measurement 